\title{
ID1 wt Allele
}

National Cancer Institute

\section{Source}

National Cancer Institute. ID1 wt Allele. NCI Thesaurus. Code C99649.

Human ID1 wild-type allele is located in the vicinity of $20 \mathrm{q} 11$ and is approximately $1 \mathrm{~kb}$ in length. This allele, which encodes DNA-binding protein inhibitor ID-1 protein, is involved in both protein heterodimerization and repression of transcription. 